Article

\title{
Antimicrobial Films Based on Nanocomposites of Chitosan/Poly(vinyl alcohol)/Graphene Oxide for Biomedical Applications
}

\author{
Sebastián Ruiz ${ }^{1}$, Julián Andrés Tamayo ${ }^{1}$, Johannes Delgado Ospina ${ }^{2}{ }^{\mathbb{C}}$, \\ Diana Paola Navia Porras ${ }^{2}$, Mayra Eliana Valencia Zapata ${ }^{1}$, José Herminsul Mina Hernandez ${ }^{1}$, \\ Carlos Humberto Valencia ${ }^{3}$, Fabio Zuluaga ${ }^{4}$ (D) and Carlos David Grande Tovar ${ }^{2 *}$ (D) \\ 1 Escuela de Ingeniería de Materiales, Facultad de Ingeniería, Universidad del Valle, Calle 13 No. 100-00, \\ Santiago de Cali 760032, Colombia; sebastian.ruiz.londono@correounivalle.edu.co (S.R.); \\ julian.tamayo@correounivalle.edu.co (J.A.T.); valencia.mayra@correounivalle.edu.co (M.E.V.Z.); \\ jose.mina@correounivalle.edu.co (J.H.M.H.) \\ 2 Grupo de Investigación Biotecnología, Facultad de Ingeniería, Universidad de San Buenaventura Cali, \\ Carrera 122 \# 6-65, Cali 76001, Colombia; jdelgado1@usbcali.edu.co (J.D.O.); \\ dpnavia@usbcali.edu.co (D.P.N.P.) \\ 3 Escuela de Odontología, Grupo Biomateriales Dentales, Universidad del Valle, Calle 13 No. 100-00, \\ Cali 76001, Colombia; carlos.humberto.valencia@correounivalle.edu.co \\ 4 Laboratorio SIMERQO, Departamento de Química, Universidad del Valle, Calle 13 No. 100-00, \\ Cali 76001,Colombia; hector.zuluaga@correounivalle.edu.co \\ 5 Programa de Química, Facultad de Ciencias, Universidad del Atlántico, Carrera 30 No. 8-49, \\ Puerto Colombia 081008, Colombia \\ * Correspondence: carlosgrande@mail.uniatlantico.edu.co; Tel.: +57-5-385-2266
}

Received: 18 February 2019; Accepted: 11 March 2019; Published: 18 March 2019

\begin{abstract}
Today, tissue regeneration is one of the greatest challenges in the field of medicine, since it represents hope after accidents or illnesses. Tissue engineering is the science based on improving or restoring tissues and organs. In this work, five formulations of chitosan/poly(vinyl alcohol)/graphene oxide (CS/PVA/GO) nanocomposites were studied for the development of biodegradable films with potential biomedical applications. The characterization of the films consisted of Fourier-transform infrared (FTIR) spectroscopy, scanning electron microscopy (SEM) and energy dispersive spectroscopy (EDS). The antibacterial activity was evaluated in vitro against Gram-positive bacteria Bacillus cereus and Staphylococcus aureus and Gram-negative Salmonella spp. and Escherichia coli, by contact of the film above inoculum bacterial in Müeller-Hinton agar. On the other hand, in vivo tests in which the material implanted in the subcutaneous tissue of Wistar rats demonstrated that the formulation CS/PVA/GO (14.25:85:0.75) was the best antibacterial film with adequate degradation in vivo. All together, these results indicate the potential of the films using nanocomposites of CS/PVA/GO in tissue engineering and cell regeneration.
\end{abstract}

Keywords: biodegradable films; chitosan; graphene oxide; poly(vinyl alcohol); tissue engineering

\section{Introduction}

Chitosan (CS) is a natural biopolymer derived from the deacetylation of chitin obtained from crustacean shells which can be processed to form films, fibers, beads, and dust [1,2]. Chitosan has become an attractive polymer for biomedical applications due to its antimicrobial properties and biocompatibility [3], with applications in tissue engineering of bone, cartilage, liver, tendons, ligaments and nerves, in wound dressings, separation membranes, blood anticoagulants, contact lenses, 
controlled release of drugs, as a fat-sequestering agent, in hydrogels and as food packaging material [4-7]. However, the high amount of hydrogen bonds of the amino and hydroxyl groups in the CS has created some inherent disadvantages, such as low mechanical properties, poor solubility in conventional solvents as well as poor stability in physiological media [8-11].

Many studies are addressing the physicochemical attributes of hybrid polymers (natural and synthetic origin), thanks to their effectiveness in overcoming the disadvantages of the naturally occurring polymer [12]. Among the fillers used are ceramic nanoparticles [13], oxides [14], and cross-linking agents [15], among other materials. However, polyvinyl alcohol/chitosan (PVA/CS) compounds are traditionally used to prepare films with improved properties, because PVA is biocompatible, which allows its use in clinical applications, membrane fabrication and tissue repair [16].

Thanks to its high mechanical resistance, chemical stability, large surface area, and low toxicity [17,18], in recent years graphene oxide (GO) has had rapid growth in biomedical applications [19]. The presence of polar groups on the surface of this material improves compatibility with polymer matrices, such as CS [20]. Also, due to its antibacterial properties and its high surface/volume ratio, the GO is a promising material for the development of antimicrobial and antiviral surfaces [21].

Although several studies on CS/PVA/GO films are in the literature, there is a lack of works where the characterization includes the physical, chemical, and mechanical evaluation of the films, together with biological tests in vitro and in vivo conditions. Therefore, this research aimed to study biodegradable films from PVA/CS formulations reinforced with GO nanofilms grouping all this characterization.

\section{Materials and Methods}

\subsection{Materials}

For GO synthesis, graphite flakes (99.8\%) were used (Alfa Aesar, Tewksbury, MA, USA). Concentrated sulfuric acid $\left(\mathrm{H}_{2} \mathrm{SO}_{4}\right)$, potassium permanganate $\left(\mathrm{KMnO}_{4}\right)$, hydrogen peroxide $\left(\mathrm{H}_{2} \mathrm{O}_{2}\right)$ and isopropanol were supplied from Merck (Burlington, MA, USA). For the production of the films, CS of low molecular weight $(144,000 \mathrm{~g} / \mathrm{mol})$ and a deacetylation degree between $89 \%$ and $90 \%$, PVA with hydrolysis between $87 \%$ and $89 \%$ and viscous molecular weight of $93,000 \mathrm{~g} / \mathrm{mol}$ (Sigma-Aldrich, Palo Alto, CA, USA). Glacial acetic acid was purchased from Merck. For the elaboration of the simulated biological fluid, $\mathrm{NaCl}, \mathrm{K}_{2} \mathrm{HPO}_{4} \cdot 3 \mathrm{H}_{2} \mathrm{O}, \mathrm{CaCl}_{2}, \mathrm{Na}_{2} \mathrm{SO}_{4}$, tris-(hydroxymethyl aminomethane) $\left[\left(\mathrm{CH}_{2} \mathrm{OH}\right)_{3} \mathrm{CNH}_{2}\right]$ were acquired from Sigma-Aldrich; $\mathrm{NaHCO}_{3}, \mathrm{KCl}, \mathrm{MgCl}_{2} \cdot 6 \mathrm{H}_{2} \mathrm{O}$ from Fisher Chemical (Pittsburgh, PA, USA) and hydrochloric acid $(\mathrm{HCl})$ from Merck. All reagents used were analytical grade.

\subsection{Methods}

\subsubsection{Graphene Oxide Synthesis}

Graphene oxide synthesis followed the methodology used by Mangadlao et al. [22]. In a round flask, $3 \mathrm{~g}$ of graphite were mixed with $400 \mathrm{~mL}$ of concentrated $\mathrm{H}_{2} \mathrm{SO}_{4}$, after $10 \mathrm{~min}$ of stirring, $3 \mathrm{~g}$ of $\mathrm{KMnO}_{4}$ were added. Subsequently, $3 \mathrm{~g}$ of $\mathrm{KMnO}_{4}$ were added every $24 \mathrm{~h}$ for three days. The reaction was stopped at four days, for which a third of the contents of the balloon was mixed in $300 \mathrm{~mL}$ of a water/ice mixture and $2 \mathrm{~mL}$ of $\mathrm{H}_{2} \mathrm{O}_{2}$ were added. The solution was distributed in $50 \mathrm{~mL}$ flasks and washed in a UNIVERSAL 320R centrifuge (Hettich, Tuttlingen, Germany) for $10 \mathrm{~min}$ at $5000 \mathrm{rpm}$ with Milli-Q water and isopropanol until reaching a neutral $\mathrm{pH}$. Subsequently, it was purified by dialysis in 3.5K MWCO SnakeSkin tubes (Thermo Scientific, Waltham, MA, USA), followed by Milli-Q water washing and drying at $-51{ }^{\circ} \mathrm{C}$ and $0.12 \mathrm{mBar}$ pressure in a Freezone 4.5 freeze dryer (LABCONCO, Kansas City, MO, USA) for $48 \mathrm{~h}$. The graphite oxide was dispersed in water for $24 \mathrm{~h}$ in a Branson 5800 ultrasound equipment (Branson, Madrid, Spain) to finally obtain the GO. 


\subsubsection{Graphene Oxide Characterization}

The GO and the starting graphite were chemically characterized by Fourier-transform infrared (FTIR) spectroscopy on an IR Affinity-1 infrared spectrophotometer (Shimadzu, Kyoto, Japan) in a range of $500-4000 \mathrm{~cm}^{-1}$ in transmittance mode using the $\mathrm{KBr}$ pellet method. The $\mathrm{X}$-ray spectra were taken on a Panalytical X'PERT PRO diffractometer (Malvern, Royston, UK) using $\mathrm{Cu}$ K $\alpha 1$ radiation $(1.540598 \AA)$ and $\mathrm{K} \alpha 2(1.544426 \AA)$, with an electron accelerator voltage of $45 \mathrm{kV}$, an electron-generating current of $40 \mathrm{~mA}$, an optical grid of incident beam $1^{\circ}$ and $1 / 2^{\circ}$ and a diffracted beam grid of $9.1 \mathrm{~mm}$, in a range $2 \theta$ between $5^{\circ}$ and $40^{\circ}$. We used the Bragg law (Equation (1)) to determine the distance between two planes of the GO network:

$$
d=\frac{\lambda}{2 \operatorname{sen} \theta}
$$

where $d$ is the lattice spacing, $\lambda$ is the $\mathrm{X}$-ray wavelength and $\theta$ is the angle of incidence.

The characteristic bands of GO and graphite were acquired by Raman spectroscopy in a Thermo Scientific X-ray diffraction (XRD) equipment (Thermo Scientific), with an excitation source of $512 \mathrm{~nm}$ at room temperature.

\subsubsection{Film Preparation}

The films were prepared according to the film casting method described by Liu et al. [23], which consisted of clearing out the solutions described in Table 1, in acetate molds and subsequently, letting cure for $24 \mathrm{~h}$ in the environment, and then $24 \mathrm{~h}$ in the oven to a temperature between 38 and $40{ }^{\circ} \mathrm{C}$, thus obtaining the solid film of CS/PVA/GO. Once collected, the test specimens were cut and conditioned for the tensile test according to ASTM D6287 and ASTM D618 standards with the dimensions specified in ASTM D882. The thickness of each specimen was determined using a Mitutoyo digital micrometer No. 293-330 (Kawasaki, Japan), from three average values along each sample. The samples were placed in a desiccator at $10 \%$ relative humidity $(\mathrm{RH})$ until the time of the test.

For the preparation of the solutions, CS was dissolved in a $2 \%(\mathrm{w} / \mathrm{v})$ acetic acid solution for $12 \mathrm{~h}$ at $80 \mathrm{rpm}$. The PVA was dissolved in distilled water for $3.5 \mathrm{~h}$ at $80{ }^{\circ} \mathrm{C}$ and $300 \mathrm{rpm}$, and finally, the GO was dispersed in distilled water using an ultrasonic bath (Branson) for $24 \mathrm{~h}$. The formulations used in this research are in Table 1.

Table 1. Formulations (F1-5) used for the preparation of nanocomposite solutions.

\begin{tabular}{cccccc}
\hline Component & F1 & F2 & F3 & F4 & F5 \\
\hline CS $(w t \%)$ & 20 & 14.75 & 19.5 & 14.25 & 29 \\
PVA (wt $\%)$ & 80 & 85 & 80 & 85 & 70 \\
GO (wt \%) & 0 & 0.25 & 0.5 & 0.75 & 1 \\
\hline CS: Chitosan; GO: Graphene oxide; PVA: Poly(vinyl alcohol).
\end{tabular}

After the solutions were prepared separately, CS and PVA were mixed by stirring at $90 \mathrm{rpm}$ for $2 \mathrm{~h}$ until a homogeneous solution was obtained which was filtered and finally, the GO dispersion was added with stirring until a homogeneous solution was obtained.

\subsubsection{Film Characterization}

Fourier-Transform Infrared Spectroscopy

The chemical identification of the films was carried out using FTIR in the attenuated total reflectance (ATR) mode (Shimadzu). 


\section{Scanning Electron Microscopy}

The morphological inspection of the surfaces of the film was carried out by scanning electron microscopy (SEM) (JEOL JSM-6490LA, Musashino, Tokyo, Japan). The working conditions were $20 \mathrm{kV}$ and mode of secondary backscattered electrons. All the samples were coated with gold, to create an electronic density in the material, since the polymers lack it.

\section{The Tensile Strength of Films}

For the tensile test, a universal SHIMADZU EZ-LZ test machine (Shimadzu) was used, following the ASTM D882 standard. Where at least five samples per formulation are required, the gap between jaws was $100 \mathrm{~mm}$, the width of the film was $20 \mathrm{~mm}$, and the test speed was $50 \mathrm{~mm} / \mathrm{min}$.

\section{Degradation in Simulated Biological Fluid}

The hydrolytic degradation was carried out following the procedure outlined in the ASTM F1635-16 standard. The films were immersed in a simulated biological fluid (SBF) at $37^{\circ} \mathrm{C}$ for seven days in a Memmert IN 110 incubator (Memmert GmbH \& Co. KG, Schwabach, Germany). The SBF was prepared according to the method proposed by Kokubo and Takadama [24] and the degradation was evaluated by examining the weight of the films before and after immersion for different periods (one, three, five, and seven days).

The initial weight of the samples before immersion was recorded as $W_{0}$ and the weight after drying for $48 \mathrm{~h}$ in the incubator at $37^{\circ} \mathrm{C}$ was recorded as $W_{d}$. The weight loss $\left(\% W_{l}\right)$ was calculated according to Equation (2):

$$
W_{l}(\%)=\frac{W_{0}-W_{d}}{W_{0}} \times 100
$$

Each sample was immersed in $15 \mathrm{~mL}$ of SBF, and in each period three samples were evaluated per formulation. The $\mathrm{pH}$ of the SBF was measured every day until the total test time was completed using an Fisherbrand ${ }^{\mathrm{TM}}$ accumet $^{\mathrm{TM}}$ AB150 pHmeter (Fischer Scientific, Inc., Ottawa, Canada). The morphology of the films after drying was studied using SEM.

\section{Antimicrobial Film Assay}

The antimicrobial activity of the films was evaluated against bacteria Bacillus cereus, Staphylococcus aureus, Salmonella spp., and Escherichia coli, by contact of the film above inoculum bacterial in agar. In short, the inoculum of each of the bacteria was carried out by adding $40 \mu \mathrm{L}$ of dilution to $10^{-6}$ colony forming units (CFU) of each of the $24 \mathrm{~h}$ growth strains in $90 \mathrm{~mm}$ diameter Petri dishes containing $20 \mathrm{~mL}$ of Müeller-Hinton agar. Subsequently, a disc with $10 \mathrm{~mm}$ of diameter of each of the prepared films was placed in the center of the box on the inoculated agar. The plates with the strains were incubated at $37^{\circ} \mathrm{C}$, and the reading of the results was carried out $24 \mathrm{~h}$ after the inoculation. The inhibition was determined as the absence of growth observed between the transparent film and the previously inoculated agar. The test was repeated three times for each of the treatments.

\section{Biomodel Tests In Vivo}

The inflammatory response to the implantation of films in the subcutaneous tissue. Samples of CS/PVA films with different percentages of GO (three replicates per formulation) with $10 \mathrm{~mm}$ in diameter and $2 \mathrm{~mm}$ in thickness were implanted in subdermal tissue of three adult Wistar rats, in preparations made on the dorsal surface, according to the recommendation of ISO 10993-6 and as reported previously [25]. As a control sample, commercial porcine collagen BioMend®(ZIMMER BIOMET, Miami, FL, USA) with the same dimensions was used. All the biomodels were supplied by the Bioterio of the Faculty of Medical Sciences of the Universidad del Valle. The procedures carried out were approved by the Animal Ethics Committee of Universidad del Valle by the CEAS 001-016 certificate. 
After 30 days of implantation, the samples were recovered, fixed in buffered formalin, dehydrated in alcohol solutions of ascending concentration (70\%, 80\%,95\%, and 100\%), diaffinized with xylol and infiltrated with paraffin for later cutting at $4 \mu \mathrm{m}$ using a Thermo ScientificTM Histoplast Paraffin ${ }^{\mathrm{TM}}$ and an Autotechnicon Tissue Processor TM (Leica Microsystems, Mannheim, Germany). The samples were processed for histological analysis by hematoxylin and eosin and Masson trichromacy techniques. For the analysis of the images, a Leica DM 750 microscope with a Leica DFC 295 camera and Leica Application Suite version 4.12.0 (Leica Microsystems, Mannheim, Germany) imaging software was used. The macroscopic images were taken with a Samsung DualView DV150F 16 MP digital camera.

\section{Results and Discussion}

\subsection{Graphene Oxide Characterization}

\subsubsection{Fourier-Transform Infrared Spectroscopy}

Figure 1 shows the FTIR spectrum of graphite and graphene oxide. For the graphite, it exhibits few absorption signals, due to the difference in the state of charges between carbon atoms. This weak difference leads to a very small induced electric dipole, which provides a very clean spectrum [26]. It is clear that when an oxidation treatment is used on the material, bands corresponding to oxygenated functional groups appear, which indicates that the oxidative process was successful. The graphene oxide spectrum showed the band at $3389 \mathrm{~cm}^{-1}$, which corresponds to the stretching vibration of the hydroxyl groups $(\mathrm{O}-\mathrm{H})$. The band at $2917 \mathrm{~cm}^{-1}$ corresponds to the vibration of the $\mathrm{C}-\mathrm{H}$ bond that is in sp $\mathrm{sp}^{3}$ hybridization. The band at $1726 \mathrm{~cm}^{-1}$ corresponds to the stretching vibration of the carbonyl group $(\mathrm{C}=\mathrm{O})$. The band at $1624 \mathrm{~cm}^{-1}$ corresponds to the stretch mode of the sp ${ }^{2}$ carbon skeletal network $(\mathrm{C}=\mathrm{C})$. It is also evident, according to some results reported in the literature, that the GO obtained contains several oxygen functional groups, such as hydroxyl, carboxyl, and epoxy groups, which correspond to the bands presented at 1417, 1226, 1048, 987, and $671 \mathrm{~cm}^{-1}[25,27,28]$.

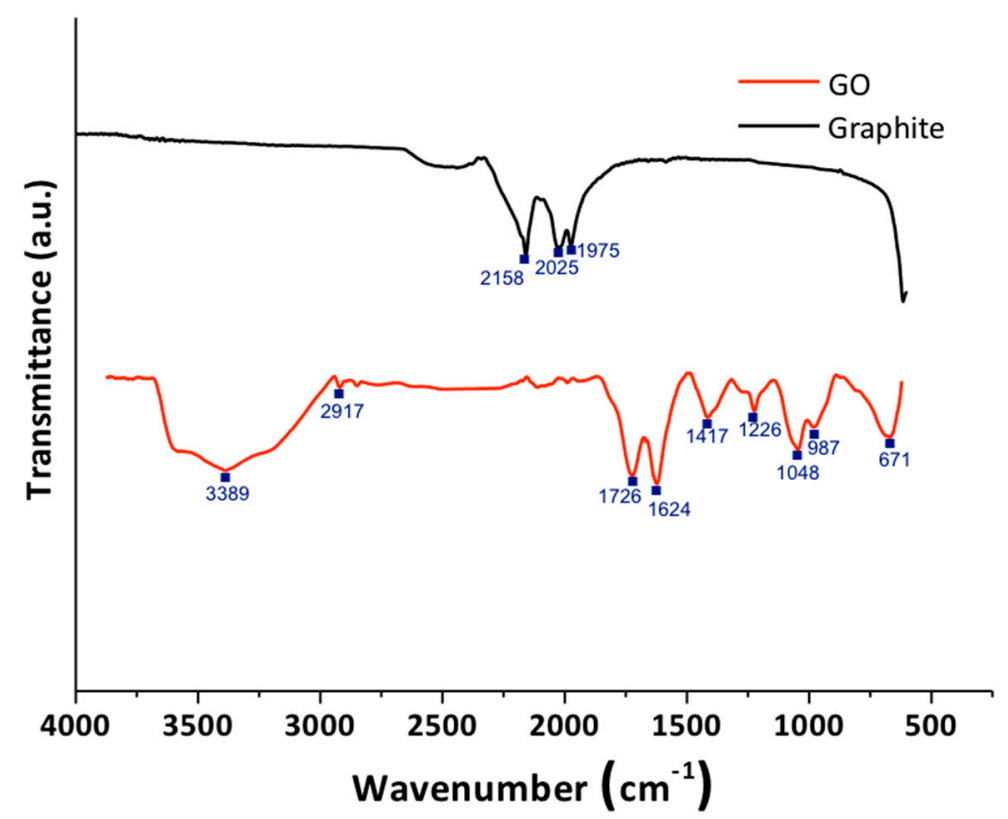

Figure 1. Fourier-transform infrared (FTIR) spectroscopy of graphite (black line) and graphene oxide (GO; red line). a.u.: Arbitrary units. 


\subsubsection{X-Ray Diffraction}

Figure 2 shows the X-ray diffraction (XRD) pattern of graphite and GO. The graphite exhibits a peak at $2 \theta=26.46^{\circ}$ which corresponds to the reflection of the plane (002), while for the GO the peak appears at $2 \theta=10.77^{\circ}$ and corresponds to the reflection of the plane (001) [29-33]. The increase in the interplanar distance of the GO in comparison with the graphite is shown in Table 2 and due to the presence of functional oxygen groups introduced by the oxidation of the graphite, which facilitate the exfoliation and hydration of the nanofilm of GO in an aqueous solution [30]. This increase in interplanar distance has been widely reported. The characteristic spacing of the GO generally ranges between 0.7 and $0.8 \mathrm{~nm}$ but may vary slightly at higher or lower values, depending on the degree of functionalization $[30,34,35]$.

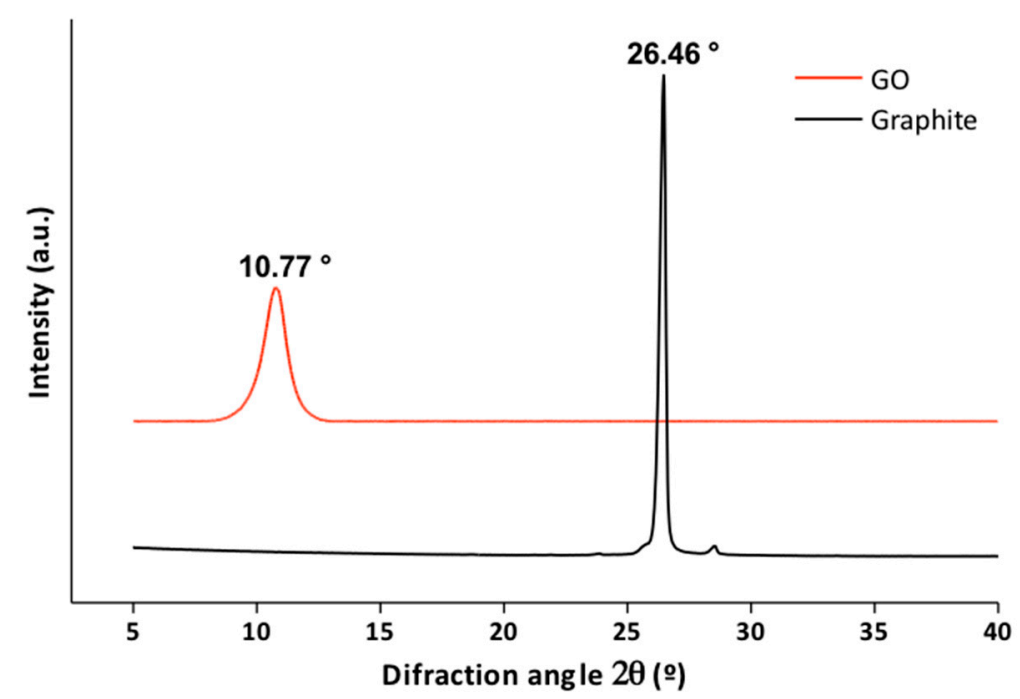

Figure 2. X-ray diffraction (XRD) of graphite (black line) and graphene oxide (GO; red line).

Table 2. Interplanar distance of graphite and GO.

\begin{tabular}{ccc}
\hline Material & Diffraction Peak $\left({ }^{\circ}\right)$ & Interlayer Distance $(\mathbf{n m})$ \\
\hline Graphite & 26.46 & 0.336 \\
GO & 10.77 & 0.82 \\
\hline \multicolumn{3}{c}{}
\end{tabular}

\subsubsection{Raman Spectroscopy}

According to the Raman spectrum for the GO shown in Figure 3, the G peak attributed to the stretching of the bond of the carbon pairs in $\mathrm{sp}^{2}$ hybridization, and the peak $\mathrm{D}$ associated with the breathing mode of the $\mathrm{sp}^{2}$ carbon rings and activated by defects caused in the graphite network due to the presence of oxygen-rich functional groups [36]. The relationship between the intensities of bands $\mathrm{D}$ and $\mathrm{G}$ is directly related to the degree of oxidation of the GO sheets [37]. 


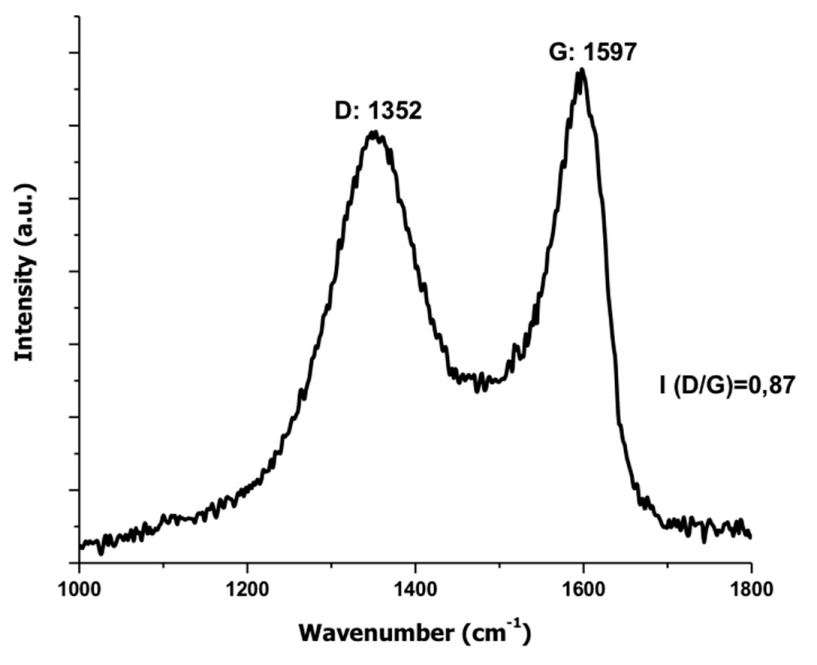

Figure 3. Raman spectrum of graphene oxide.

\subsection{Film Characterization}

\subsubsection{Fourier-Transform Infrared Spectroscopy}

In Figure 4 it is observed that an absorption band appears at $1701 \mathrm{~cm}^{-1}$ related to the stretching vibration of $\mathrm{C}=\mathrm{O}$ carboxyl groups at the $\mathrm{GO}$ edges. The band of vibration associated with the $-\mathrm{OH}$ group $\left(1328 \mathrm{~cm}^{-1}\right)$ becomes more pronounced with the increase of the GO content due to the destruction of the original hydrogen bonds of CS/PVA compounds and the formation of a strong interaction between CS, PVA, and GO. The C-OH bond, observed at $1382 \mathrm{~cm}^{-1}$, is weakened due to the increase in GO due to the strong hydrogen bond. Besides, the band at $3251 \mathrm{~cm}^{-1}$ (stretching vibration of the $-\mathrm{OH}$ group) was displaced to higher values $\left(3288 \mathrm{~cm}^{-1}\right)$ and was further extended, due to the interaction of the GO with the CS/PVA mixture by hydrogen bonds [35].

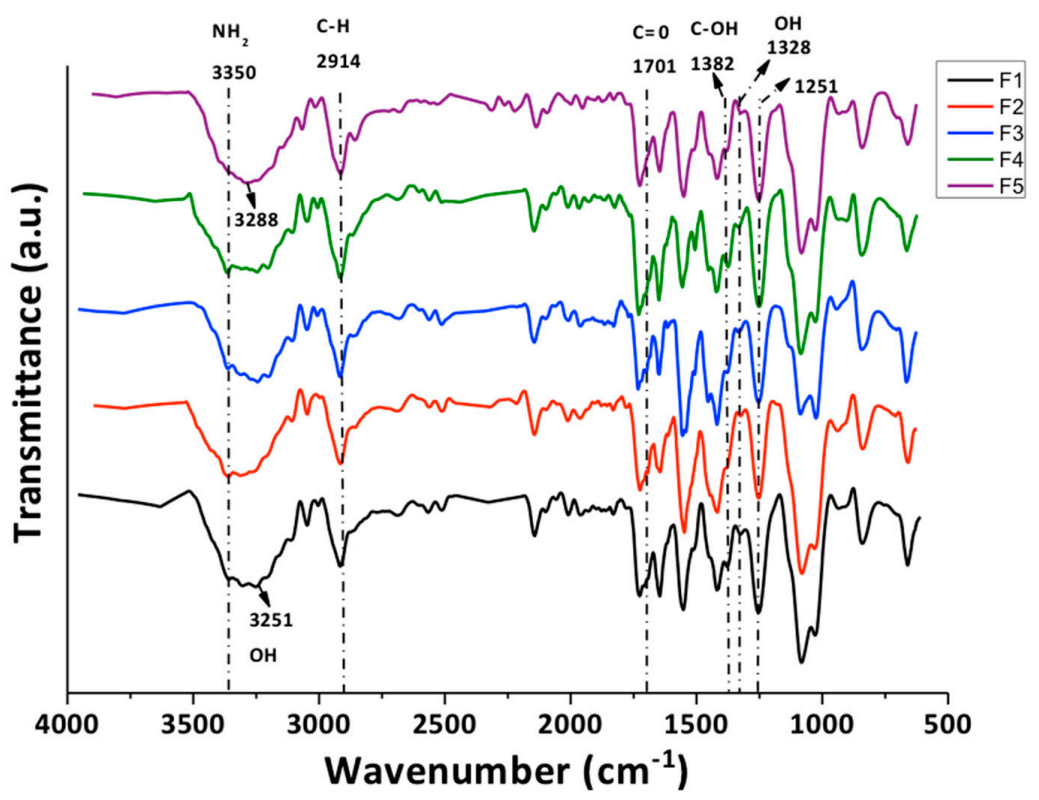

Figure 4. Attenuated total reflectance Fourier-transform infrared (ATR-FTIR) spectroscopy of chitosan/poly(vinyl alcohol)/graphene oxide (CS/PVA/GO) films for the five formulations. F1: CS/PVA/GO 20:80:0; F2: CS/PVA/GO 14.75:85:0.25; F3: CS/PVA/GO 19.5:80:0.5; F4: CS/PVA/GO 14.25:85:0.75 and F5: CS/PVA/GO 29:70:1. All the ratios are wt \%. 


\subsubsection{Scanning Electron Microscopy}

As shown in the SEM micrographs (Figure 5), an increase in the roughness of the film surface is evidenced in the different formulations, the morphology of the films changes from a smooth structure for formulation F1 (F1; Figure 5A), to an utterly rough morphology for formulation F5 (F5; Figure 5E). Previous studies have shown that the surface of pure CS and PVA films separately is smooth, continuous and compact [16,38], so it is expected that the mixture between them will also present a surface with the same conditions, which is consistent with the results found, because the PVA offers good compatibility when incorporated into polysaccharides such as CS. By adding GO to the CS/PVA mixture, the GO nanosheets generate an increase in the roughness of the films due to their texture [35]. There is also a specific porosity which is possibly associated with the rapid evaporation of the solvent during the curing of the films, air bubbles or separation of polysaccharide molecules during the curing process of the films [16].

In general, CS/PVA films were transparent, which can be explained by the inherent property of PVA and the amorphous nature of chitosan [35]. With GO content increasing, there was an increase in the intensity of the black tone and consequently an increase in the opacity of the film [39].
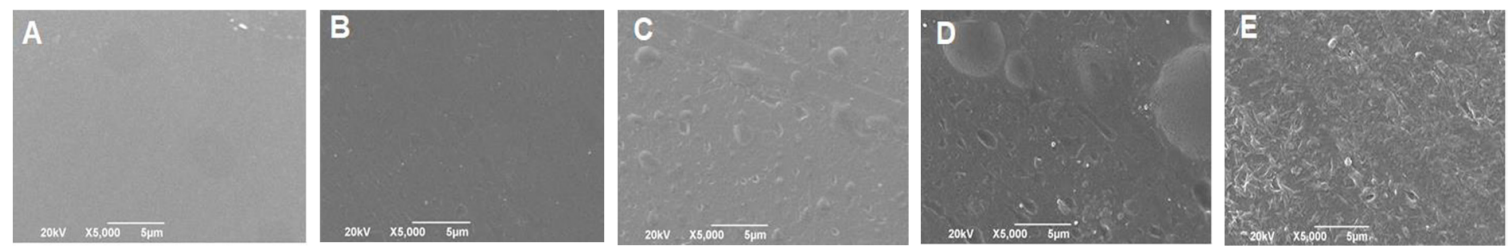

Figure 5. Morphology of CS/PVA/GO films. (A) F1: CS/PVA/GO 20:80:0; (B) F2: CS/PVA/GO 14.75:85:0.25 ); (C) F3: CS/PVA/GO 19.5:80:0.5; (D) F4: CS/PVA/GO 14.25:85:0.75; (E) F5: CS/PVA/GO 29:70:1. All the ratios are wt $\%$.

\subsubsection{The Tensile Strength of the Films}

As shown in Figure 6, the tensile strength is affected by the fraction of each component. It is evident that the presence of GO in percentages lower than $1 \mathrm{wt} \%$ improves the traction properties of the films. It is evident that the incorporation of high fractions of PVA/CS, as well as small portions of GO, increases the tensile strength of the films. This reinforcing effect is attributed to the good GO sheets dispersion in the PVA/CS matrix, acting as a nanocharge that absorbs a good part of the force applied to the film. Also, it is due to the union between the amino groups of the CS and the carboxyl groups on the surface of the GO through covalent bonds and hydrogen bonds, thus contributing to the reinforcement of the films due to the formation of these molecular bonds [40].

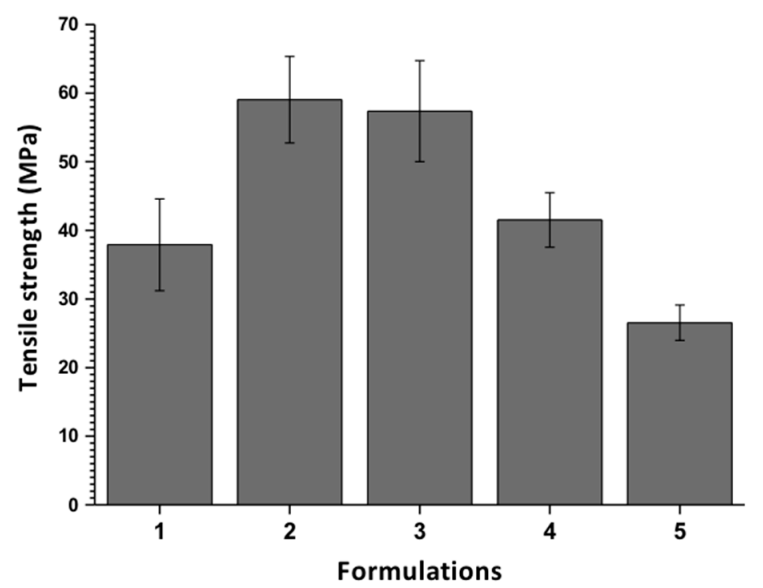

Figure 6. The tensile strength of CS/PVA/GO films. Data are shown as mean \pm standard deviation of the mean $(n=5)$. 


\subsubsection{Degradation in a Simulated Biological Fluid}

\section{Weight Loss}

Figure 7 shows the results of the degradation percentage (weight loss) of the films with different proportions of GO during the seven days of immersion in SBF. The incorporation of GO in the polymeric matrix increased the stability of the films against SBF since the percentage of weight loss after seven days of immersion decreased from $86.95 \%$ for formulation F1 that did not contain GO up to $33 \%$ for the formulation F5 comprising 1\% GO. This behavior is because the GO in the CS/PVA binary mixture gives the material a higher number of hydrogen bonds between the CS and the GO, which provide the material with high chemical stability in the polymer chains of the CS [41].

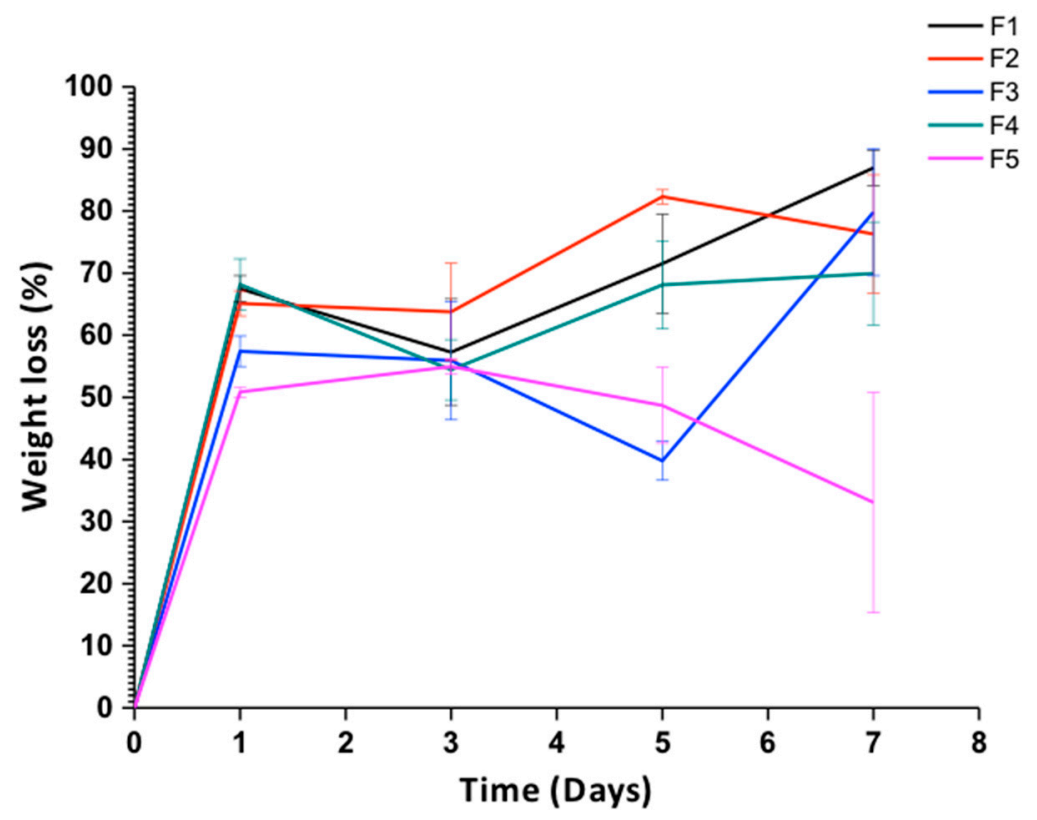

Figure 7. Weight loss vs. time. F1: CS/PVA/GO 20:80:0; F2: CS/PVA/GO 14.75:85:0.25; F3: CS/PVA/GO 19.5:80:0.5; F4: CS/PVA/GO 14.25:85:0.75 and F5: CS/PVA/GO 29:70:1. All the ratios are $w t \%$. Data are shown as mean \pm standard deviation of the mean $(n=3)$.

$\mathrm{pH}$ Changes

Figure 8 shows the $\mathrm{pH}$ changes in the SBF during the immersion period of the samples. The decrease observed in the $\mathrm{pH}$ when increasing the time of immersion of the samples in the SBF is associated with the attack to the amorphous zones of the polymers because they retain more acidic species and because they have greater susceptibility to degradation according to the research by Figueira-Maldonado et al. [42]. Besides, the detachment of the degradation by-products typical of CS such as glucosamine and $\mathrm{N}$-acetylglucosamine contribute to said $\mathrm{pH}$ reduction, so that the formulations with higher CS content (formulations F1 and F5) show more significant reductions in the $\mathrm{pH}$ values. These by-products of CS degradation are found in the extracellular matrix of human tissue, making them harmless when released into the body [43]. The $\mathrm{pH}$ of the biological media is a fundamental constant for the maintenance of the vital processes since the enzymatic action, and the chemical transformations of the cells are carried out within a $\mathrm{pH}$ range between 6 and 8 [44-46]. All the formulations studied showed $\mathrm{pH}$ variations within the permissible range in the human body to promote life and maintenance of vital functions. 


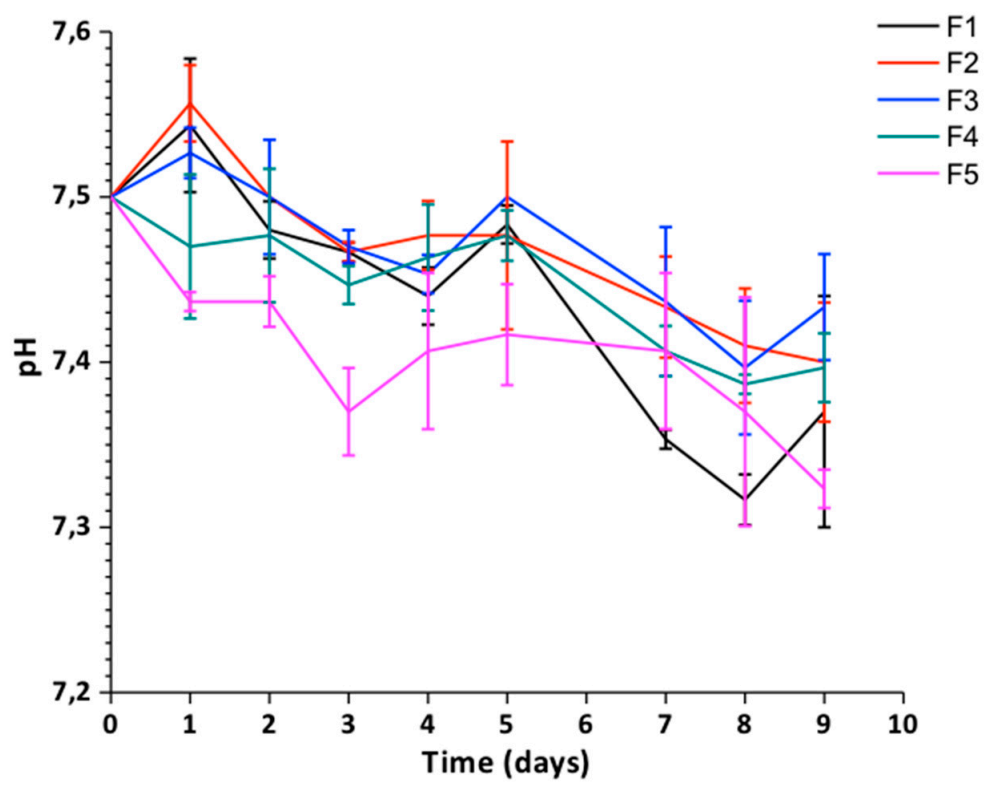

Figure 8. Study of the $\mathrm{pH}$ solution vs. immersion time in simulated body fluid (SBF) of the films. F1: CS/PVA/GO 20:80:0; F2: CS/PVA/GO 14.75:85:0.25; F3: CS/PVA/GO 19.5:80:0.5; F4: CS/PVA/GO 14.25:85:0.75 and F5: CS/PVA/GO 29:70:1. All the ratios are wt $\%$. Data are shown as mean \pm standard deviation of the mean $(n=3)$.

Scanning Electron Microscopy of the Films after Immersion in Simulated Body Fluid

Figure 9 shows SEM images of the CS/PVA/GO films after their immersion in SBF. The highly rough texture is due to the degradation process of the nanocomposite, which increases with GO content. Calcium phosphate deposition of a layer on the surface films can also be observed, which could be determined by energy dispersive spectroscopy (EDS) with a calcium composition of $36.70 \%$ and $16.4 \%$ phosphorus for formulation F2 (Supplementary Table S1). The deposition of said apatite layer on the surface (red arrows in Figure 9B) is suitable for a bioactive material since it promotes the interaction between the material and the surrounding tissue [47].

The morphological structure of the deposited layer presents typical morphological characteristics of apatite structures (globular structures), similar to those reported by different authors for materials with bioactive traits [48]. The morphology of the films before and after the immersion in SBF can be seen in Figures 5 and 9, respectively, where an evident difference in the texture of the surface is noted.
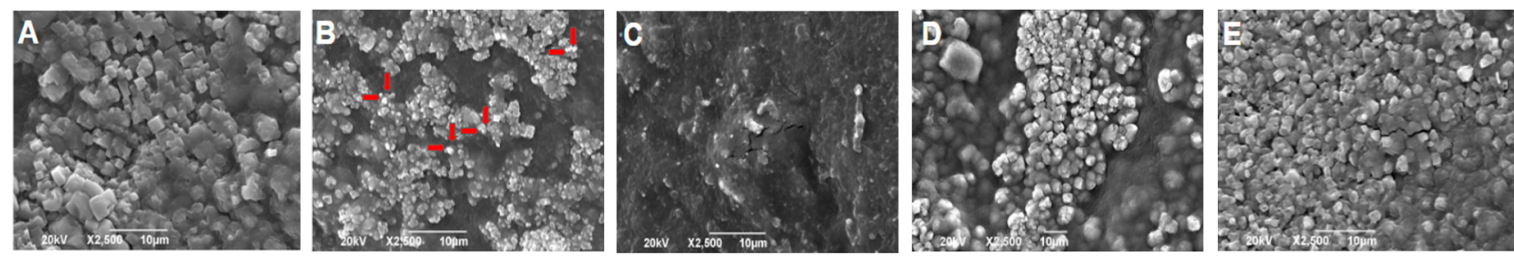

Figure 9. Morphology of CS / PVA / GO films after seven days in the degradation process in SBF. (A) F1: CS/PVA/GO 20:80:0; (B) F2: CS/PVA/GO 14.75:85:0.25; (C) F3: CS/PVA/GO 19.5:80:0.5;

(D) F4: CS/PVA/GO 14.25:85:0.75; (E) F5: CS/PVA/GO 29:70:1. All the ratios are wt \%.

\subsubsection{Antibacterial Activity}

As shown in Table 3, no inhibition was observed for films that did not contain GO. Although some authors have demonstrated that chitosan shows activity against Gram-positive and Gram-negative bacteria, due to the loss of intracellular constituents [49,50], our results agree with other authors [51], which suggest that chitosan must be dissolved to observe antimicrobial effect, because PVA improves hydrogen bonds with chitosan, decreasing its solubility [52]. 
In the films with added GO, the results at $24 \mathrm{~h}$ of incubation showed that the addition contributes to completely inhibit the growth of the strains treated with $0.75 \%$ of GO and with a greater inhibition than $1.0 \%$, an effect similar to what happens when essential oils are incorporated [53]. The strain with the least inhibition was S. aureus, which showed partial restraint at the concentration of $0.25 \%$ of GO, indicating that there is higher resistance by Gram-negative bacteria to inhibition due to CS/PVA effect. The GO effect suggests an interaction at the level of the cell membrane.

The dependence of the antibacterial activity on GO content, coincides with some investigations that show the GO has an inhibitory effect on the growth of Gram-positive bacteria, such as S. aureus [54,55], and Gram-negative, such as E. coli [54,56-59] and Pseudomonas aeruginosa [60], through damage to the cell membrane of bacteria when they come into contact with GO. Damage to the membrane can be caused by the sharp atomic edges of graphene, which can penetrate the cell membrane and physically disturb its integrity and also through lipid peroxidation induced by the oxidative nature of GO [61]. Oxidative stress is considered as an essential component of antimicrobial activity for bacterial cells exposed to GO [62].

Table 3. Inhibition of CS/PVA/GO films against bacterial strains.

\begin{tabular}{cccccc}
\hline Strain & F1 & F2 & F3 & F4 & F5 \\
\hline Bacillus cereus & - & ++ & ++ & +++ & +++ \\
Staphylococcus aureus & - & ++ & ++ & +++ & +++ \\
Salmonella spp & - & - & ++ & +++ & +++ \\
Escherichia coli & - & ++ & ++ & +++ & +++
\end{tabular}

$(+++)$ Complete inhibition of the pathogen; (++) Weak inhibition of the pathogen; (-) Weak pathogen growth; (-) Complete growth of the pathogen. F1: CS/PVA/GO 20:80:0; F2: CS/PVA/GO 14.75:85:0.25; F3: CS/PVA/GO 19.5:80:0.5; F4: CS/PVA/GO 14.25:85:0.75; F5: CS/PVA/GO 29:70:1. All the ratios are wt \%.

\subsubsection{Biomodel Tests In Vivo}

After 30 days of implantation in the biomodels, the recovery of the samples was performed, and in all cases, repair of the surgical defect created was observed. All the biomodels presented hair recovery (Figure 10A) and the absence of injuries and infections in the intervened areas with normal healing of the tissue architecture (Figure 10B,C). The material is initially compatible, an inflammatory reaction to a foreign body is apparent where the cells surround the fragments with a fibrous capsule and the rest of the soft tissues with regular appearance.
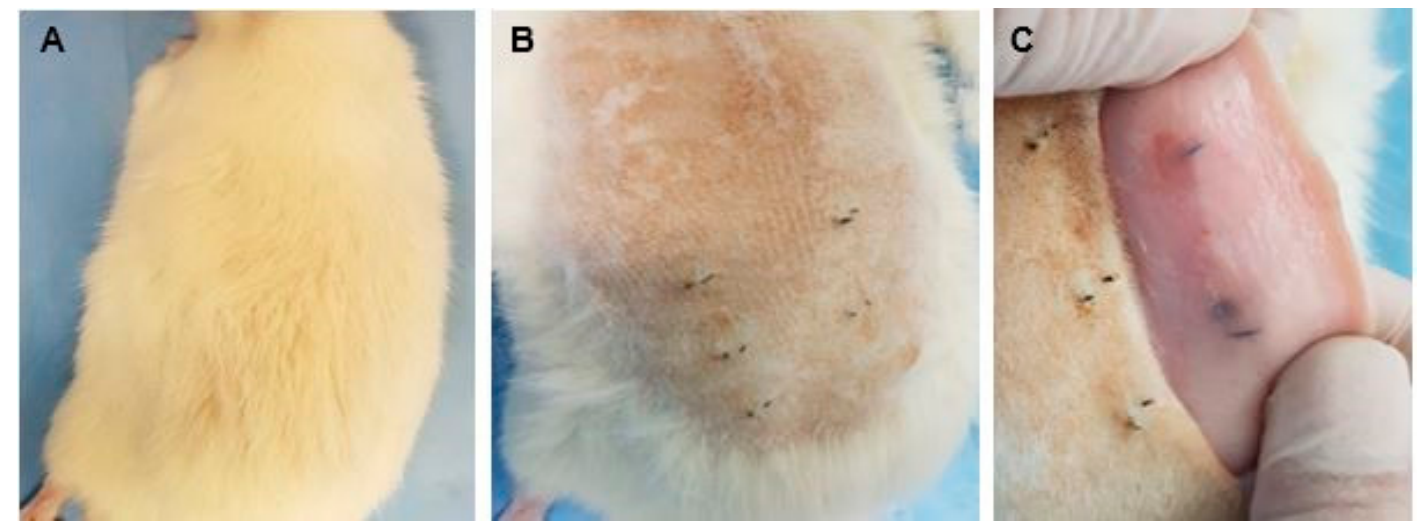

Figure 10. The dorsal area where the implantation was performed after 30 days. (A) Hair recovery; (B) absence of injuries and infections; (C) internal surface of the skin where the implanted samples encapsulated by scar tissue.

Figure 11, Figure 12, and Figure 13 correspond to the histological analysis of the subcutaneous cellular tissue (SCT) of the biomodels (Wistar rats) with CS/PVA/GO films implanted. It is apparent 
that the control sample (porcine collagen) has been wholly reabsorbed and the healing is typical with a recovery of the tissue architecture (Figure 11A-C).
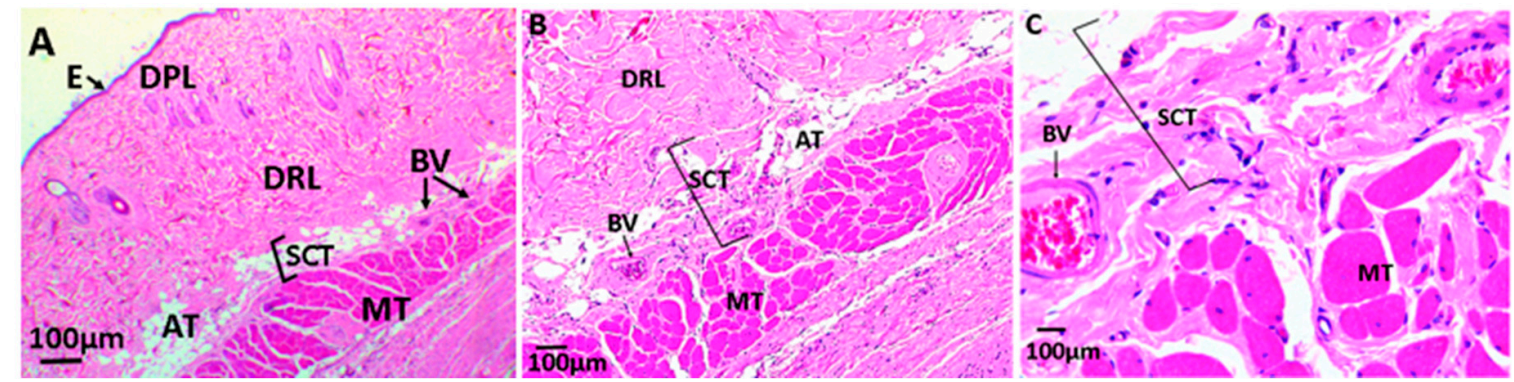

Figure 11. (A-C) Histological analysis of sample control. E: Epidermis; DPL: Dermis papillary layer; DRL: Dermis reticular Layer; BV: Blood vessels; AT: Adipose tissue; MT: Muscular tissue; SCT:

Subcutaneous cellular tissue. (A) $4 \times$; (B) $10 \times$; (C) $40 \times$.

In the experimental formulation F2 (CS/PVA/GO 14.75:85:0.25) and F3 (CS/PVA/GO 19.5:80:0.5), normal healing is observed, and small film pieces remain with the presence of inflammatory cells surrounding them (Figure 12).

The samples with GO content at 0.25 and $0.5 \%$ showed more significant evidence of degradation, and less inflammatory response, the presence of inflammatory infiltrate being greater in the sample of F3(19.5CS/80PVA/0.5GO) (Figure 12A-C).
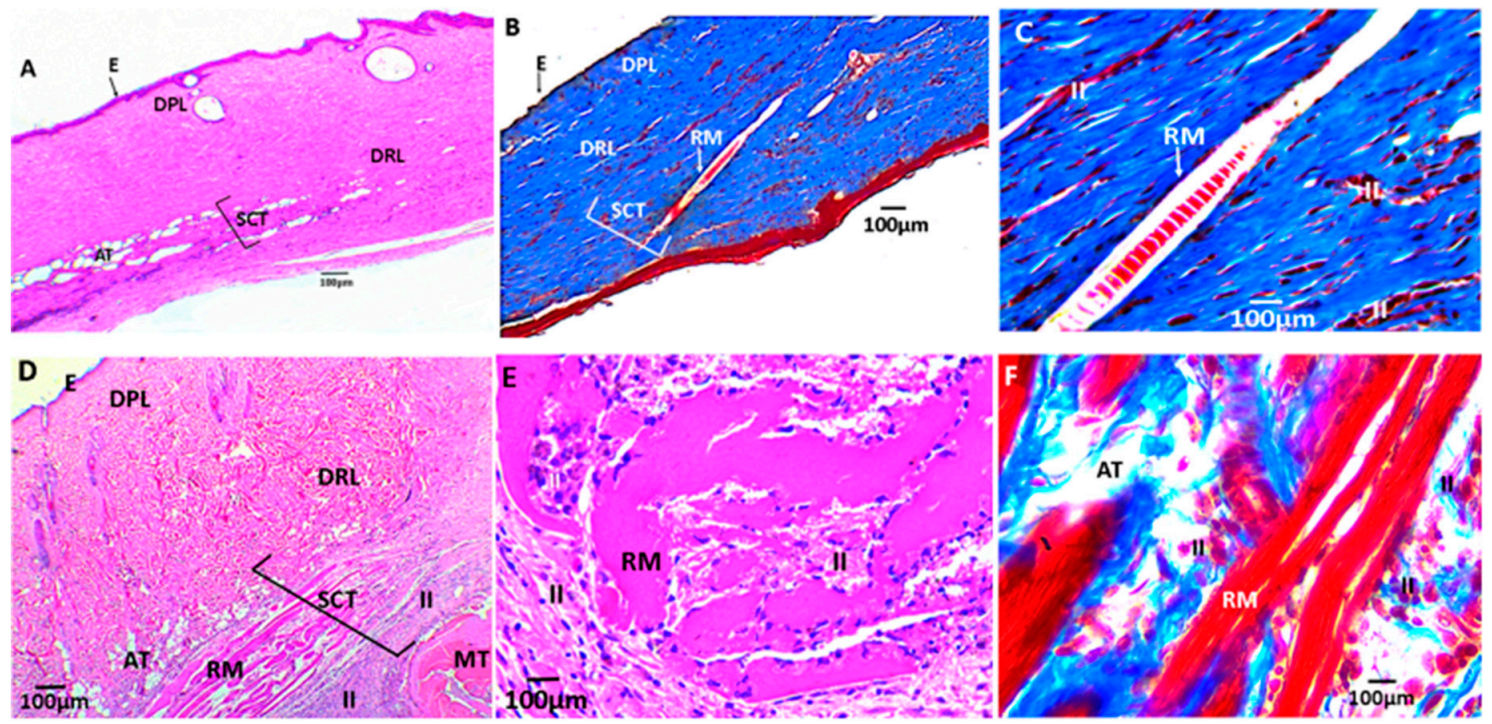

Figure 12. Histological analysis of experimental samples: (A-C) formulation F2 (CS/PVA/GO 14.75:85:0.25) and (D-F) formulation F3 (CS/PVA/GO 19.5:80:0.5). All the ratios are wt \%. E: Epidermis; DPL: Dermis papillary layer; DRL: Dermis reticular layer; BV: Blood vessels; AT: Adipose tissue; H: Hypodermis; MT: Muscular tissue; SCT: Subcutaneous cellular tissue; RM: Remnant material; II: Inflammatory infiltrate. (A) $4 \times$; (B) $10 \times$; (C) $40 \times$; (D) $4 \times$; (E) $10 \times$; (F) $40 \times$.

The formulations with $0.75 \mathrm{wt} \%$ and $1 \mathrm{wt} \%$ GO present less evidence of degradation and a greater inflammatory infiltrate. In Figure 13A,B, two zones of degradation are observed: Z1 with poorly degraded films and $\mathrm{Z} 2$ with highly fragmented films that are in the process of degradation by inflammatory cells. Figure $13 \mathrm{C}$ corresponds to zone $\mathrm{Z1}$ at $40 \times$.

Figure 13D-F correspond to films with a GO content of $1 \%$. There is very little evidence of degradation, and at $40 \times$ the films surrounded by inflammatory cells are observed, starting the reabsorption at their edges. 

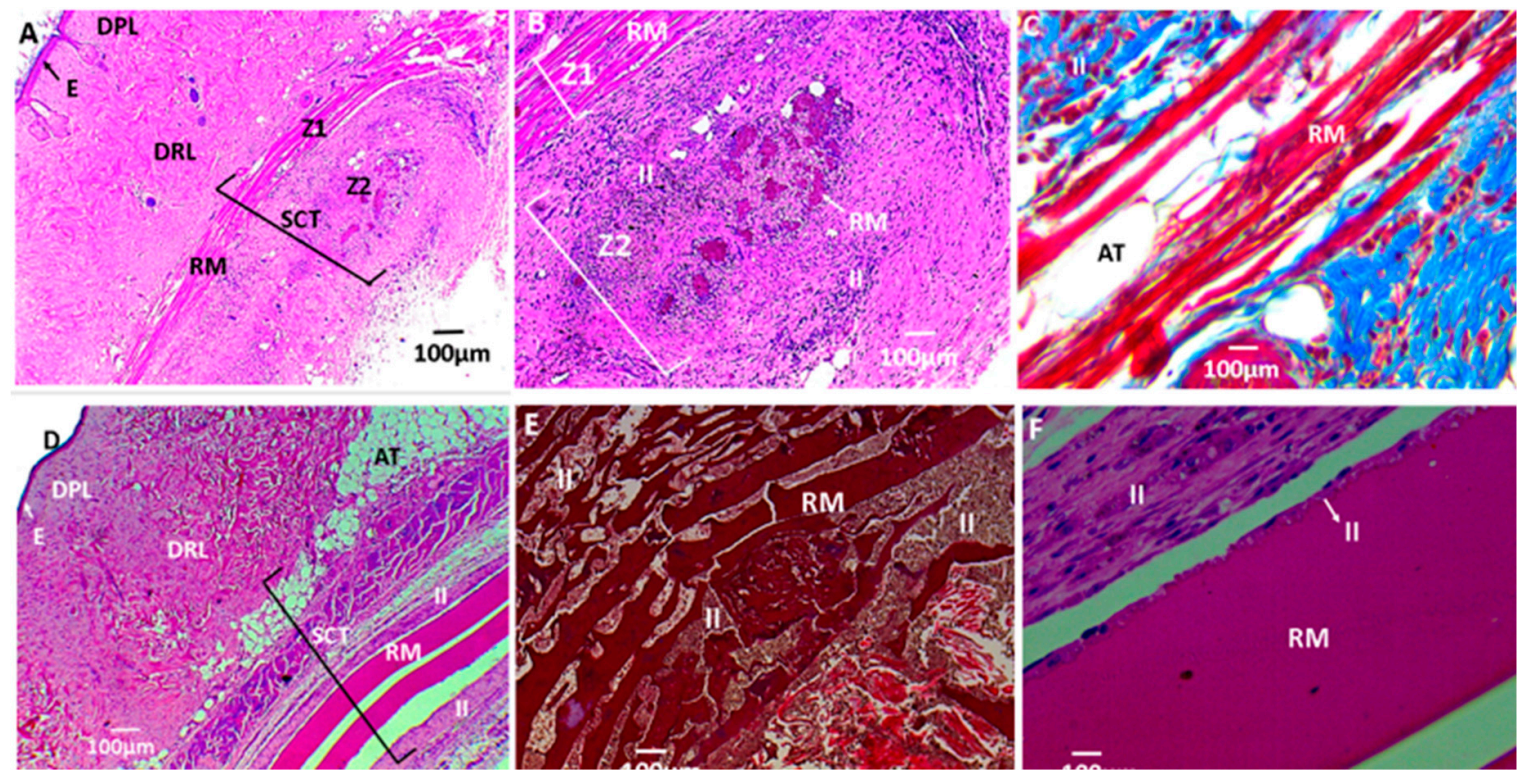

Figure 13. Histological analysis of experimental samples: (A-C) formulation F4 (CS/PVA/GO 14.25:85:0.75) and (D-F) formulation F5 (CS/PVA/GO 29:70:1). All the ratios are wt \%. E: Epidermis; DPL: Dermis papillary layer; DRL: Dermis reticular layer; BV: Blood vessels; AT: Adipose tissue; H: Hypodermis; MT: Muscular tissue; SCT: Subcutaneous cellular tissue; RM: Remnant material; II: Inflammatory infiltrate; Z1: Zone 1; Z2: Zone 2. (A) 4×; (B) 10×; (C) 40×; (D) $4 \times$; (E) 10×; (F) $40 \times$.

The histological results show that the implanted materials are stimulating a typical foreign body reaction, which is the mechanism typically used by living beings to phagocytose subdermal implanted materials [63-66].

The degradation of the CS/PVA/GO films through fragmentation and phagocytosis is caused by cells belonging to an inflammatory infiltrate and their replacement with healthy tissue. Recovery of the standard architecture (Figures 12 and 13), is an indication of a biocompatible material that eventually will be degraded entirely/reabsorbed by a foreign body reaction, with moderate GO content dependence as previously reported $[25,67,68]$.

\section{Conclusions}

Films based on CS/PVA/GO nanocomposites were obtained, which showed suitable properties from the mechanical, chemical, and biological point of view for their application in tissue engineering.

The addition of GO to CS/PVA films generated an increase in tensile strength, surface roughness, and degradation time in both SBF and implanted in the biomodels. Also, the antimicrobial activity of the films against the bacteria studied, showed an increase with the content of GO, mainly because the mechanisms of inhibition of the bacterial growth of the GO are generated by contact between the GO and the cell membrane of the bacteria.

After SBF films immersion, a light layer of calcium phosphate was generated on the surface of the material, which is usually related to a bioactive material.

The films with $0.75 \mathrm{wt} \%$ of GO were the best formulation with complete growth inhibition of the tested bacteria and advanced degradation in vivo with low foreign inflammatory response of the tissue, demonstrating its potential for application in films for tissue engineering.

Supplementary Materials: The following are available online at http:/ / www.mdpi.com/2218-273X/9/3/109/s1, Table S1: Energy dispersive X-ray spectroscopy (EDS) results of the formulation F2.

Author Contributions: Conceptualization, S.R., J.A.T., M.E.V.Z. and J.H.M.H.; methodology, S.R., J.A.T., M.E.V.Z., J.H.M.H., C.H.V., J.D.O., D.P.N.P. and C.D.G.T.; writing-original draft preparation, S.R., J.A.T., M.E.V.Z., J.H.M.H., C.H.V. and J.D.O.; writing-review and editing, M.E.V.Z., C.H.V., F.Z. and C.D.G.T.; supervision, F.Z.; funding acquisition, F.Z. 
Funding: This research was funded by la Vicerrectoria de Investigaciones de la Universidad del Valle (Proyecto 71066) y la Universidad de San Buenaventura Seccional Cali.

Conflicts of Interest: The authors declare no conflict of interest.

\section{References}

1. Yuste, J.R.; del Pozo, J.L.; Quetglás, E.G.; Azanza, J.R. Infecciones más comunes en el paciente trasplantado. Anales del Sistema Sanitario de Navarra 2006, 29 (Suppl. 2), 175-206. [CrossRef] [PubMed]

2. Gutha, Y.; Pathak, J.L.; Zhang, W.; Zhang, Y.; Jiao, X. Antibacterial and wound healing properties of chitosan/poly(vinyl alcohol)/zinc oxide beads (CS/PVA/ZnO). Int. J. Biol. Macromol. 2017, 103, 234-241. [CrossRef] [PubMed]

3. Lim, H.N.; Huang, N.M.; Loo, C.H. Facile preparation of graphene-based chitosan films: Enhanced thermal, mechanical and antibacterial properties. J. Non-Cryst. Solids 2012, 358, 525-530. [CrossRef]

4. Dash, M.; Chiellini, F.; Ottenbrite, R.M.; Chiellini, E. Chitosan-A versatile semi-synthetic polymer in biomedical applications. Prog. Polym. Sci. 2011, 36, 981-1014. [CrossRef]

5. Rinaudo, M. Chitin and chitosan: Properties and applications. Prog. Polym. Sci. 2006, 31, 603-632. [CrossRef]

6. Kumar, M.N.R. A review of chitin and chitosan applications. React. Funct. Polym. 2000, 46, 1-27. [CrossRef]

7. Honarkar, H.; Barikani, M. Applications of biopolymers I: Chitosan. Monatshefte fur Chemie 2009, 140, 1403-1420. [CrossRef]

8. Szymańska, E.; Winnicka, K. Stability of Chitosan-A Challenge for Pharmaceutical and Biomedical Applications. Mar. Drugs 2015, 13, 1819-1846. [CrossRef]

9. Anitha, A.; Sowmya, S.; Kumar, P.T.S.; Deepthi, S.; Chennazhi, K.P.; Ehrlich, H.; Tsurkan, M.; Jayakumar, R. Chitin and chitosan in selected biomedical applications. Prog. Polym. Sci. 2014, 39, 1644-1667. [CrossRef]

10. Shao, L.; Chang, X.; Zhang, Y.; Huang, Y.; Yao, Y.; Guo, Z. Graphene oxide cross-linked chitosan nanocomposite membrane. Appl. Surf. Sci. 2013, 280, 989-992. [CrossRef]

11. Rodríguez-Vázquez, M.; Vega-Ruiz, B.; Ramos-Zúñiga, R.; Saldaña-Koppel, D.A.; Quiñones-Olvera, L.F. Chitosan and its potential use as a scaffold for tissue engineering in regenerative medicine. Biomed Res. Int. 2015, 2015, 821279. [CrossRef]

12. Kanimozhi, K.; Basha, S.K.; Kumari, V.S. Processing and characterization of chitosan/PVA and methylcellulose porous scaffolds for tissue engineering. Mater. Sci. Eng. C 2016, 61, 484-491. [CrossRef] [PubMed]

13. Saber-Samandari, S.; Saber-Samandari, S. Biocompatible nanocomposite scaffolds based on copolymer-grafted chitosan for bone tissue engineering with drug delivery capability. Mater. Sci. Eng. C 2017, 75, 721-732. [CrossRef] [PubMed]

14. Saravanan, S.; Anjali, C.; Vairamani, M.; Sastry, T.P.; Subramanian, K.S.; Selvamurugan, N. Scaffolds containing chitosan, gelatin and graphene oxide for bone tissue regeneration in vitro and in vivo. Int. J. Biol. Macromol. 2016, 104, 1975-1985. [CrossRef]

15. Adhikari, U.; Rijal, N.P.; Khanal, S.; Pai, D.; Sankar, J.; Bhattarai, N. Magnesium incorporated chitosan-based scaffolds for tissue engineering applications. Bioact. Mater. 2016, 1, 132-139. [CrossRef] [PubMed]

16. Ma, Q.; Liang, T.; Cao, L.; Wang, L. Intelligent poly (vinyl alcohol)-chitosan nanoparticles-mulberry extracts films capable of monitoring $\mathrm{pH}$ variations. Int. J. Biol. Macromol. 2018, 108, 576-584. [CrossRef]

17. Wang, C.; Mallela, J.; Garapati, U.S.; Ravi, S.; Chinnasamy, V.; Girard, Y.; Howell, M.; Mohapatra, S. A chitosan-modified graphene nanogel for noninvasive controlled drug release. Nanomedicine 2013, 9, 903-911. [CrossRef] [PubMed]

18. Simsek, E.B.; Saloglu, D.; Ozcan, N.; Novak, I.; Berek, D. Carbon fiber embedded chitosan/PVA composites for decontamination of endocrine disruptor bisphenol-A from water. J. Taiwan Inst. Chem. Eng. 2017, 70, 291-301. [CrossRef]

19. Botas, C.; Álvarez, P.; Blanco, P.; Granda, M.; Blanco, C.; Santamaría, R.; Romasanta, L.J.; Verdejo, R.; López-Manchado, M.A.; Menéndez, R. Graphene materials with different structures prepared from the same graphite by the Hummers and Brodie methods. Carbon 2013, 65, 156-164. [CrossRef]

20. Wang, Y.; Shen, C.; Lou, W.; Shentu, F. Fiber optic humidity sensor based on the graphene oxide/PVA composite film. Opt. Commun. 2016, 372, 229-234. [CrossRef] 
21. Ye, S.; Shao, K.; Li, Z.; Guo, N.; Zuo, Y.; Li, Q.; Lu, Z.; Chen, L.; He, Q.; Han, H. Antiviral activity of graphene oxide: How sharp edged structure and charge matter. ACS Appl. Mater. Interfaces 2015, 7, 21571-21579. [CrossRef]

22. Mangadlao, J.D.; de Leon, A.C.C.; Felipe, M.J.L.; Cao, P.; Advincula, P.A.; Advincula, R.C. Grafted carbazole-assisted electrodeposition of graphene oxide. ACS Appl. Mater. Interfaces 2015, 7, 10266-10274. [CrossRef]

23. Liu, M.; Zhou, Y.; Zhang, Y.; Yu, C.; Cao, S. Preparation and structural analysis of chitosan films with and without sorbitol. Food Hydrocoll. 2013, 33, 186-191. [CrossRef]

24. Kokubo, T.; Takadama, H. How useful is SBF in predicting in vivo bone bioactivity? Biomaterials 2006, 27, 2907-2915. [CrossRef]

25. Valencia, C.; Valencia, C.; Zuluaga, F.; Valencia, M.; Mina, J.; Grande-Tovar, C. Synthesis and application of scaffolds of chitosan-graphene oxide by the freeze-drying method for tissue regeneration. Molecules 2018, 23, 2651. [CrossRef]

26. Lopez mata, C.; Aguilar, J.; Peña, Y. Caracterización óptica y morfologica de materiales compuestos de P3OT y nanotubos de carbono funcionalizados. Química Hoy 2012, 2, 18-23.

27. Nikkhah, S.; Tahermansouri, H.; Chekin, F. Synthesis, characterization, and electrochemical properties of the modified graphene oxide with 4,4'-methylenedianiline. Mater. Lett. 2018, 211, 323-327. [CrossRef]

28. Saleem, H.; Haneef, M.; Abbasi, H.Y. Synthesis route of reduced graphene oxide via thermal reduction of chemically exfoliated graphene oxide. Mater. Chem. Phys. 2018, 204, 1-7. [CrossRef]

29. Martínez, V.G.; Lopez, R.M.; Velasco, C.B. Estudio de la Estabilidad del Óxido de Grafeno con el Tiempo. Master's Thesis, Universidad de Oviedo, Asturias, Spain, 2013.

30. Goumri, M.; Poilâne, C.; Ruterana, P.; Doudou, B.B.; Wéry, J.; Bakour, A.; Baitoul, M. Synthesis and characterization of nanocomposites films with graphene oxide and reduced graphene oxide nanosheets. Chin. J. Phys. 2017, 55, 412-422. [CrossRef]

31. Liu, B.; Zhang, D.; Li, X.; He, Z.; Guo, X.; Liu, Z.; Guo, Q. Effect of graphite flakes particle sizes on the microstructure and properties of graphite flakes/copper composites. J. Alloys Compd. 2018, 766, 382-390. [CrossRef]

32. Bao, C.; Guo, Y.; Song, L.; Hu, Y. Poly(vinyl alcohol) nanocomposites based on graphene and graphite oxide: A comparative investigation of property and mechanism. J. Mater. Chem. 2011, 21, 13942-13950. [CrossRef]

33. Morimune, S.; Nishino, T.; Goto, T. Poly(vinyl alcohol)/graphene oxide nanocomposites prepared by a simple eco-process. Polym. J. 2012, 44, 1056-1063. [CrossRef]

34. Ionita, M.; Vasile, E.; Crica, L.E.; Voicu, S.I.; Pandele, A.M.; Dinescu, S.; Predoiu, L.; Galateanu, B.; Hermenean, A.; Costache, M. Synthesis, characterization and in vitro studies of polysulfone/graphene oxide composite membranes. Compos. Part B Eng. 2015, 72, 108-115. [CrossRef]

35. Pandele, A.M.; Ionita, M.; Crica, L.; Dinescu, S.; Costache, M.; Iovu, H. Synthesis, characterization, and in vitro studies of graphene oxide/chitosan-polyvinyl alcohol films. Carbohydr. Polym. 2014, 102, 813-820. [CrossRef]

36. Pei, S.; Wei, Q.; Huang, K.; Cheng, H.M.; Ren, W. Green synthesis of graphene oxide by seconds timescale water electrolytic oxidation. Nat. Commun. 2018, 9, 145. [CrossRef] [PubMed]

37. López-Díaz, D.; Holgado, M.L.; García-Fierro, J.L.; Velázquez, M.M. Evolution of the Raman spectrum with the chemical composition of graphene oxide. J. Phys. Chem. C 2017, 121, 20489-20497. [CrossRef]

38. Pinotti, A.; García, M.A.; Martino, M.N.; Zaritzky, N.E. Study on microstructure and physical properties of composite films based on chitosan and methylcellulose. Food Hydrocoll. 2007, 21, 66-72. [CrossRef]

39. Yadav, I.; Nayak, S.K.; Rathnam, V.S.; Banerjee, I.; Ray, S.S.; Anis, A.; Pal, K. Reinforcing effect of graphene oxide reinforcement on the properties of poly (vinyl alcohol) and carboxymethyl tamarind gum based phase-separated film. J. Mech. Behav. Biomed. Mater. 2018, 81, 61-71. [CrossRef]

40. Khan, Y.H.; Islam, A.; Sarwar, A.; Gull, N.; Khan, S.M.; Munawar, M.A.; Zia, S.; Sabir, A.; Shafiq, M.; Jamil, T. Novel green nanocomposites films fabricated by indigenously synthesized graphene oxide and chitosan. Carbohydr. Polym. 2016, 146, 131-138. [CrossRef] [PubMed]

41. Ruan, J.; Wang, X.; Yu, Z.; Wang, Z.; Xie, Q.; Zhang, D.; Huang, Y.; Zhou, H.; Bi, X.; Xiao, C.; et al. Enhanced physiochemical and mechanical performance of chitosan-grafted graphene oxide for superior osteoinductivity. Adv. Funct. Mater. 2016, 26, 1085-1097. [CrossRef] 
42. Maldonado, E.F. Degradación Hidrolitica a Diferentes $p H$ de un Material Compuesto Poli(ácido láctico)/Quitosano; Trabajo de Grado, Universidad Simón Bolívar: Sartenejas, Venezuela, 2008.

43. Depan, D.; Shah, J.S.; Misra, R.D.K. Degradation mechanism and increased stability of chitosan-based hybrid scaffolds cross-linked with nanostructured carbon: Process-structure-functional property relationship. Polym. Degrad. Stab. 2013, 98, 2331-2339. [CrossRef]

44. American Society of Testing Materials. ASTM F1635-16, Standard Test Method for In Vitro Degradation Testing of Hydrolytically Degradable Polymer Resins and Fabricated Forms for Surgical Implants; American Society of Testing Materials: West Conshohocken, PA, USA, 2016; pp. 1-5.

45. Fiñana, I.T.; Cejudo, A.G.; Fernández, E. pH y amortiguadores: Tampones fisiológicos. Amortiguadoras 2001, 3,1-11.

46. Maruyama, M.; Ito, M. In vitro properties of a chitosan-bonded self-hardening paste with hydroxyapatite granules. J. Biomed. Mater. Res. 1996, 32, 527-532. [CrossRef]

47. Mokhtari, H.; Ghasemi, Z.; Kharaziha, M.; Karimzadeh, F.; Alihosseini, F. Chitosan-58S bioactive glass nanocomposite coatings on $\mathrm{TiO}_{2}$ nanotube: Structural and biological properties. Appl. Surf. Sci. 2018, 441, 138-149. [CrossRef]

48. Solís, Y.; Davidenko, N.; Carrodeguas, R.G.; Cruz, J.; Hernández, A.; Cameron, R.E.; Peniche, C. Evaluación in vitro de composites basados en quitosana e hidroxiapatita. IFMBE Proc. 2013, 33, 96-99.

49. Hall-Stoodley, L.; Costerton, J.W.; Stoodley, P. Bacterial biofilms: From the natural environment to infectious diseases. Nat. Rev. Microbiol. 2004, 2, 95-108. [CrossRef] [PubMed]

50. Schelegueda, L.I.; Gliemmo, M.; Campos, C.A. Action of chitosan, nisin, and sodium lactate on the inhibition and cell membrane damage of Listeria innocua and Shewanella putrefaciens. In Worldwide Research Efforts in the Fighting against Microbial Pathogens: From Basic Research to Technological Developments; Méndez-Vilas, A., Ed.; Brown Walker Press: Boca Raton, FL, USA, 2013; pp. 3-7.

51. Zivanovic, S.; Chi, S.; Draughon, A.F. Antimicrobial activity of chitosan films enriched with essential oils. J. Food Sci. 2005, 70, M45-M51. [CrossRef]

52. Zu, Y.; Zhang, Y.; Zhao, X.; Shan, C.; Zu, S.; Wang, K.; Li, Y.; Ge, Y. Preparation and characterization of chitosan-polyvinyl alcohol blend hydrogels for the controlled release of nano-insulin. Int. J. Biol. Macromol. 2012, 50, 82-87. [CrossRef] [PubMed]

53. Grande-Tovar, C.D.; Serio, A.; Delgado-Ospina, J.; Paparella, A.; Rossi, C.; Chaves-Lopez, C. Chitosan films incorporated with Thymus capitatus essential oil: Mechanical properties and antimicrobial activity against degradative bacterial species isolated from tuna (Thunnus sp.) and swordfish (Xiphias gladius). J. Food Sci. Technol. 2018, 55, 4256-4265. [CrossRef] [PubMed]

54. Akhavan, O.; Ghaderi, E. Toxicity of graphene and graphene oxide nanowalls against bacteria. ACS Nano 2010, 4, 5731-5736. [CrossRef]

55. Chen, H.; Gao, D.; Wang, B.; Zhao, R.F.; Guan, M.; Zheng, L.N.; Zhou, X.Y.; Chai, Z.F.; Feng, W.Y. Graphene oxide as an anaerobic membrane scaffold for the enhancement of B. adolescentis proliferation and antagonistic effects against pathogens E. coli and S. aureus. Nanotechnology 2014, 25, 165101. [CrossRef] [PubMed]

56. Liu, S.; Zeng, T.H.; Hofmann, M.; Burcombe, E.; Wei, J.; Jiang, R.; Kong, J.; Chen, Y. Antibacterial activity of graphite, graphite oxide, graphene oxide, and reduced graphene oxide: Membrane and oxidative stress. ACS Nano 2011, 5, 6971-6980. [CrossRef] [PubMed]

57. Kumar, S.; Raj, S.; Kolanthai, E.; Sood, A.K.; Sampath, S.; Chatterjee, K. Chemical functionalization of graphene to augment stem cell osteogenesis and inhibit biofilm formation on polymer composites for orthopedic applications. ACS Appl. Mater. Interfaces 2015, 7, 3237-3252. [CrossRef] [PubMed]

58. Castrillón, S.R.; Perreault, F.; de Faria, A.F.; Elimelech, M. Interaction of graphene oxide with bacterial cell membranes: Insights from force spectroscopy. Environ. Sci. Technol. Lett. 2015, 2, 112-117. [CrossRef]

59. Hu, W.; Peng, C.; Luo, W.; Lv, M.; Li, X.; Li, D.; Huang, Q.; Fan, C. Graphene-based antibacterial paper. ACS Nano 2010, 4, 4317-4323. [CrossRef]

60. Gurunathan, S.; Han, J.W.; Dayem, A.A.; Eppakayala, V.; Kim, J.H. Oxidative stress-mediated antibacterial activity of graphene oxide and reduced graphene oxide in Pseudomonas aeruginosa. Int. J. Nanomed. 2012, 7, 5901-5914. [CrossRef] [PubMed]

61. Fan, J.; Grande, C.D.; Rodrigues, D.F. Biodegradation of graphene oxide-polymer nanocomposite films in wastewater. Environ. Sci. Nano 2017, 4, 1808-1816. [CrossRef] 
62. Perreault, F.; de Faria, A.F.; Nejati, S.; Elimelech, M. Antimicrobial properties of graphene oxide nanosheets: Why size matters. ACS Nano 2015, 9, 7226-7236. [CrossRef] [PubMed]

63. Anderson, J.M.; Rodriguez, A.; Chang, D.T. Foreign body reaction to biomaterials. Semin. Immunol. 2008, 20, 86-100. [CrossRef]

64. Van Putten, S.M.; Ploeger, D.T.A.; Popa, E.R.; Bank, R.A. Macrophage phenotypes in the collagen-induced foreign body reaction in rats. Acta Biomater. 2013, 9, 6502-6510. [CrossRef]

65. Klopfleisch, R. Macrophage reaction against biomaterials in the mouse model-Phenotypes, functions, and markers. Acta Biomater. 2016, 43, 3-13. [CrossRef] [PubMed]

66. Qian, Y.; Li, L.; Song, Y.; Dong, L.; Chen, P.; Li, X.; Cai, K.; Germershaus, O.; Yang, L.; Fan, Y. Surface modification of nanofibrous matrices via layer-by-layer functionalized silk assembly for mitigating the foreign body reaction. Biomaterials 2018, 164, 22-37. [CrossRef] [PubMed]

67. Mariana, I.; Mihail, G.; Aiza, W.; Stefan, I.; Burns, J.S.; Iovu, H. Graphene and functionalized graphene: Extraordinary prospects for nanobiocomposite materials. Compos. Part B 2017, 121, 34-57.

68. Ryon, S.; Li, Y.C.; Jang, H.L.; Khoshakhlagh, P.; Akbari, M.; Nasajpour, A.; Zhang, Y.S.; Tamayol, A.; Khademhosseini, A. Graphene-based materials for tissue engineering. Adv. Drug Deliv. Rev. 2016, 105, 255-274.

(C) 2019 by the authors. Licensee MDPI, Basel, Switzerland. This article is an open access article distributed under the terms and conditions of the Creative Commons Attribution (CC BY) license (http://creativecommons.org/licenses/by/4.0/). 